\title{
IMPACT OF A COMMON CORPORATE TAX BASE ON THE EFFECTIVE TAX BURDEN IN BELGIUM
}

\section{Annelies Roggeman ${ }^{1}$, Isabelle Verleyen ${ }^{2}$, Philippe Van Cauwenberge ${ }^{3}$, Carine Coppens ${ }^{4}$}

\author{
1, 2, ${ }^{4}$ Faculty of Business and Information Management, University College Ghent, Valentin \\ Vaerwyckweg 1, B-9000 Ghent, Belgium \\ ${ }^{3}$ Department of Accountancy and Corporate Finance, Ghent University, Sint-Pietersplein 7, \\ B-9000 Ghent, Belgium \\ E-mails: ${ }^{1}$ Annelies.Roggeman@hogent.be; ${ }^{2}$ Isabelle.Verleyen@hogent.be (corresponding \\ author); ${ }^{3}$ Philippe.Vancauwenberge@ugent.be; ${ }^{4}$ Carine.Coppens@hogent.be
}

Received 28 February 2013; accepted 20 May 2013

\begin{abstract}
In March 2011, the European Commission launched a proposal for a Common Consolidated Corporate Tax Base (CCCTB). However, a Common Corporate Tax Base (CCTB), leaving consolidation and apportionment out of consideration, appears to be a more realistic proposition for corporate tax harmonization in Europe. Using the European Tax Analyzer (ETA), we simulate the impact of the CCTB on the effective tax burden in Belgium. The results show that the adoption of the CCTB increases the Belgian effective tax burden by $16 \%$. This remarkable increase is mainly driven by the fact that national tax deductions are not allowed under CCTB. This study allows policymakers to gain insight into the size effects of certain corporate tax measures and contributes to the current discussion on corporate tax harmonization in Europe.
\end{abstract}

Keywords: CCTB, effective tax burden, Belgium, simulation, ETA, CCCTB.

Reference to this paper should be made as follows: Roggeman, A.; Verleyen, I.; Van Cauwenberge, P.; Coppens, C. 2014. Impact of a Common Corporate Tax Base on the effective tax burden in Belgium, Journal of Business Economics and Management 15(3): 530-543.

JEL Classification: F23, H20, H25, H87.

\section{Introduction}

In March 2011, the European Commission (EC) launched a proposal for a Common Consolidated Corporate Tax Base (CCCTB) (EC 2011). The goal of this optional tax system is to remove the underlying causes of all tax obstacles currently harming the international competitiveness of European multinationals (EC 2001). The tax liability of a company belonging to a CCCTB group would be determined by applying four distinct steps. Firstly, each group member has to calculate its taxable profit according to the same set of rules, i.e. the Common Corporate Tax Base (CCTB). Secondly, the individual tax bases are summed up to the consolidated tax base while taking into ac- 
count the elimination of intra-group transactions and loss compensation. Thirdly, the consolidated tax base is allocated to the different group members by means of an apportionment formula. Finally, each member state has the right to apply its own tax rate to the specific share of the overall tax base (Schön et al. 2008).

Recent studies (Bettendorf et al. 2010) exploring the macro-economic impact of introducing a CCCTB find that the system would not yield substantial welfare gains for Europe. The variation of welfare effects across countries is large and highly depends on the design of the apportionment formula. A less-far reaching and therefore more achievable approach would be the introduction of a CCTB. This policy option would affect the calculation of the corporate tax base by introducing a common set of tax accounting rules for all member states. At a later stage, consolidation and apportionment of the individual tax bases could be included, which transforms the CCTB into a CCCTB system. As some member states have clearly expressed scepticism about the feasibility of CCCTB, the CCTB approach appears to be a more realistic proposition for corporate tax harmonization in Europe (Oestreicher et al. 2009). In this respect, also the FrenchGerman intention to introduce a harmonized tax system could have an impact on the implementation of a CCTB in Europe ${ }^{1}$.

Using the European Tax Analyzer (ETA), Spengel et al. (2012) simulate the impact of a CCTB on the effective tax burden of companies in all 27 EU member states. The results show that the effective tax burden would, on an EU average, remain largely unchanged $(-0.06 \%)$.

One of the great merits of the study of Spengel et al. (2012) is that the effective tax burden effect is measured for each of the EU member states. Moreover, this large-scale approach gives the opportunity to assess the effective tax burden for Europe as a whole. However, such an approach is very time-consuming and a limitation of this study is that it is unfeasible to address all national tax regulations in great detail. Also, the study of Spengel et al. (2012) explains the most important differences between the losing and winning countries and does not have the intention to stress the tax burden effect for one country in particular.

Our research contributes to the existing literature in two ways. First, contrary to the previous literature, we focus on the impact of a CCTB on the effective tax burden for Belgian companies in particular. Specifically, we compare the effective tax burden under CCTB with the tax burden under the Belgian tax system and investigate the isolated impact of the implemented tax measures. In order to do this, we extent the latest version of the ETA taking into account the Belgian tax measures stimulating R\&D. We also implement particular measures for SMEs like the increased percentage for notional interest deduction and the reduced tax rates. As regards CCTB, we apply all rules as recently proposed by the EC (EC 2011). These rules, for example, deal with assumptions concerning depreciation and valuation of inventories. Second, we contribute to the

1 In a letter to European Council President Herman Van Rompuy, German Chancellor Merkel and the former French President Sarkozy revealed their intention to introduce a common corporate tax base and tax rate in 2013 (Paris, $16^{\text {th }}$ August, 2011). 
existing literature by studying under which conditions the CCTB could be an attractive choice for Belgian companies and by including policy recommendations that could be relevant for other European countries.

In general, the results show that the adoption of the proposed CCTB remarkably increases the tax burden by $16 \%$. This finding is mainly driven by the fact that Belgian companies are not allowed to apply the notional interest deduction under CCTB.

\section{Recent reforms of corporate taxation}

In Belgium, an important corporate tax reform was introduced in 2003 when the nominal tax rate was reduced from $40.17 \%$ to $33.99 \%$ (Valenduc 2004). One of the scarce studies in Belgium concerning corporate tax reforms is that of Vandenbussche et al. (2005). The authors show that the effective tax rate for large Belgian companies steadily increased over the period 1993-2002. They also argue that the government anticipated the large reduction in the statutory tax rate in 2003 by widening the tax base in the years just before that reduction.

In spite of the important decrease of the nominal tax rate in 2003, additional reforms were introduced in the following years with the aim to spur investment and promote R\&D. For example, the deduction for patent income and the deduction or tax credit for investments improving the environment were introduced in tax year 2007. Another remarkable measure in Belgium was the introduction of the allowance for corporate equity (ACE) in tax year 2006, i.e. the so-called notional interest deduction (NID). This measure allows companies to deduct from their taxable profits a fictious interest calculated on the basis of their corporate equity and tackles the fiscal discrimination between equity and debt financing (Valenduc 2004). For a sample of Belgian SMEs, Kestens et al. (2012) find that the adoption of the NID declined the marginal tax rates from $29 \%$ to $2.9 \%$.

Corporate tax reforms were not only introduced at the national level, but also at the European level. In October 2001, the European Commission (EC) published the report 'Company Taxation in the Internal market' (EC 2001) in which the main tax obstacles for companies were described. By tackling all these obstacles, the Commission believes that CCCTB would be the best comprehensive solution to stimulate the international competitiveness of European multinationals (EC 2001). Eventually, in March 2011 the EC launched a proposal for a Council directive on a CCCTB (EC 2011).

Oestreicher and Koch (2011) assess the revenue consequences of using a CCCTB in the EU member states. Their results reveal that total tax revenue would be reduced by $4.56 \%$ when CCCTB would be compulsory and by $4.65 \%$ when CCCTB would be optional.

Other studies explore the macro-economic consequences of the proposed EU reforms for a CCCTB. Using a numerical computable general equilibrium (CGE) model for Europe, Bettendorf et al. (2010) suggest that on an EU-average neither a common tax base nor a consolidation with formula apportionment would yield substantial welfare 
gains. However, the variation of effects across countries is large and highly depends on the choice of the apportionment formula. As the published EC documents lack clarity about the technical details of consolidation and apportionment, some authors have stick to the system of a CCTB (Spengel et al. 2012). Haverals (2007) relies on the preparing documents of the EC and uses IAS/IFRS as a starting point for the development of a CCTB. The study shows that the application of IAS/IFRS in Belgium would broaden the tax burdens of companies by 3.8-14.6\% depending on their sector. Using the ETA, Spengel et al. (2012) study the impact of a CCTB in Europe. However, in this study CCTB is applied according to the proposal which defines CCTB as a common set of autonomous tax accounting rules without explicit reference to IAS/IFRS. Their results show that the differences between the proposed CCTB and national accounting rules have a small impact on the tax burden. Only five countries have positive or negative changes above $2 \%$.

\section{Research set-up and methodology}

In this paper, we focus on the impact of a CCTB on the effective tax burden for Belgian companies in particular and examine the following research questions:

- To what extent does the effective tax burden for an average company differ when applying CCTB instead of the Belgian tax system?

- What is the size of the impact on the tax burden when the implemented tax rules of CCTB and the Belgian system are considered in isolation?

- How could CCTB be an attractive choice for Belgian companies if the system would be optional?

To answer these research questions, we use the ETA (Spengel, Oestreicher 2012) developed by the Centre for European Economic Research and the University of Mannheim. It is the first micro-simulation model which measures the average tax burden ${ }^{2}$ taking into account a detailed assessment of all major elements forming the corporate tax base. For example, the model takes into account depreciation rules and thin capitalization rules. Thus, the ETA goes beyond prior approaches ${ }^{3}$ by setting up an explicit link between financial accounting and tax accounting. The ETA (Spengel, Oestreicher 2012) calculates and compares effective average tax burdens for companies located in one of the EU-27 member states. The absolute effective average tax burden is derived from simulating the development of a company over a 10 year period and is defined as the difference between the pre-tax value and the post-tax value of the firm at the end of the simulation period.

In the first step, the pre-tax value of the firm in period 10 is determined. This equals the sum of the estimated pre-tax cash flows and the value of net assets at the end of the simulation period. The pre-tax cash flows are based on estimates for cash receipts

2 For a discussion about measuring the average versus marginal tax burden we refer to Fullerton (1984) and Devereux and Griffith (2003).

3 See Schanz and Schanz (2010) and Finke et al. (forthcoming) for a discussion on existing corporate micro-simulation models. 
and cash expenses in each period. The value of net assets in period 10 is calculated by deducting the liabilities of the corporation from the assets. In the second step, the posttax value of the firm at the end of the simulation period is calculated. The determination of the post-tax value of the firm only has cash flow effects and no impact on the value of the net assets. So, the post-tax value is expressed as the pre-tax value of the firm minus the cash flows due to tax liabilities in each period and minus the cash flows for possible hidden reserves and liabilities at the end of the simulation period. In order to determine the absolute amount of tax liabilities in each period, receipts and expenses are entered into the balance sheet and/or into the tax profit and loss account following national taxation rules or CCTB rules. After having applied the national tax rates, other relevant components such as tax credits are taken into account to calculate the amount of tax liabilities. The impact in percentage of the different elements of CCTB on the tax burden can be written as follows:

Impact tax burden $(\%)=$

$$
\frac{\left(\text { FutureValue }_{\text {pretax }}-\text { FutureValue }_{\text {post-tax }, \text { CCTB }}\right)-\left(\text { FutureValue }_{\text {pretax }}-\text { FutureValue }_{\text {post-tax }, \text { NAT GAAP }}\right)}{\left(\text { FutureValue }_{\text {pretax }}-\text { FutureValue }_{\text {post-tax }, \text { NAT GAAP }}\right)} .
$$

The ETA uses empirical data, mainly taken from the Amadeus database to form one large and one small or medium-sized (SME) EU-27 average company ${ }^{4}$. Publicly owned companies and companies with a legal form (e.g. partnerships) or industry (e.g. mining) that are not relevant are left out. Additionally, companies for which the required data are not available are excluded (Spengel, Oestreicher 2012).

\section{Description of the Belgian tax system and the Common Corporate Tax Base}

\subsection{The Belgian tax system}

In accordance with Belgian corporate tax law, the distributed as well as the retained profits are subject to income tax. These taxable profits result from the costs and revenues mentioned in the profit and loss account. The profit before tax will be subject to several adjustments in order to obtain the taxable income. In what follows, we consider the main tax adjustments taken into account in the ETA ${ }^{5}$.

- Applying the Belgian tax code, assets have to be depreciated individually over their useful lives (pooling is not allowed). Straight line depreciation is obliged for intangible fixed assets. In the ETA, intangibles are depreciated at a rate of $20 \%{ }^{6}$. For tangible fixed assets, double declining balance or straight line depreciation is allowed. In the ETA, the most favourable option from a tax perspective is applied.

4 For the balance sheets and financial ratios of the large company and SME at the end of year 6, we refer to Spengel and Oestreicher (2012: 15-16).

5 For a complete overview of the Belgian tax rules and all its conditions we refer to the Belgian Income tax code of 1992.

6 In the ETA intangibles only consist of patents and licenses. 
For buildings, straight line depreciation is used. Office buildings are depreciated at a depreciation rate of $3 \%$, while factory buildings are depreciated at $5 \%$. For machinery, factory and office equipment, the double declining balance method is used.

- The depreciation base comprises any costs connected with the construction of a fixed asset. In the ETA, only direct costs are included in the depreciation base. In Belgium, cost of R\&D can be only capitalized under certain conditions. For reasons of simplicity, R\&D costs are directly expensed in the ETA.

- Different valuation methods for inventories are allowed in Belgium: The LIFO method is used in the ETA, being the most favourable one from a tax perspective.

- Interest expenses are deductible from the taxable basis. However, a 7:1 debt/equity ratio applies if the creditor is exempt or taxed at a reduced rate in respect of the interest paid on the debt. Interests related to debt in excess of this ratio are considered as non-deductible business expenses. Due to computational limitations, the simulations with ETA take into account a 1:1 debt/equity ratio.

- Interests and royalty payments derived from a non-resident company are subject to corporate income tax. To avoid double taxation, a credit method is applied for the withholding taxes paid and for the taxes paid abroad.

In addition to these adjustments, some specific tax deductions are allowed in the Belgian tax system. However, these deductions need to be applied in a fixed order and cannot lead to a fiscal loss. In what follows, we explain the deductions applied in the ETA in more detail:

- In order to avoid double taxation, the Belgian tax legislator introduced an exemption for domestic and foreign dividend income, also called the participation exemption (PE). First, the gross dividends received from subsidiaries are included in the taxable base of the parent company. Second, $95 \%$ of the amount of dividends is deducted from the taxable base. In case of insufficient taxable profit, the unused PE can be carried forward indefinitely.

- Since assessment year 2007, companies are allowed to deduct from their taxable profits a fictitious interest rate calculated on the basis of their corrected equity, i.e. the NID. With this ACE, the tax authority wants to eliminate the fiscal discrimination between financing through debt and financing through own resources. Each tax year, the NID rate is determined on the basis of the average rate for Belgian 10-year linear treasury bonds. For companies recognized as SME, this rate is increased by $0.5 \%$. In order to get rational simulation results, the percentage for NID is in line with the long term debt assumption made in the ETA, namely $5.1 \%$. The unused NID can be carried forward for seven years.

- In order to create an attractive investment climate, the Belgian tax legislation allows for a deduction on innovative investments or investments improving the environment. The investment deduction reduces the taxable basis with a certain percentage of the depreciation base ${ }^{7}$. Due to model restrictions in the ETA, we only apply an investment deduction for patents, which is calculated as $13.5 \%$ of the depreciation

7 For certain investments, the deduction can be spread in time. See the Belgian Corporate Income Tax Code 1992 for more details. 
base. The unused investment deduction can be carried forward indefinitely. Important to mention is that companies can also choose for a patent tax credit instead of an investment deduction. This tax credit equals $33.99 \%$ of the amount of the investment deduction. The tax credit is non-refundable, but can be carried forward for four years. After this period, the unused balance can be refunded the year after. The applied tax rate equals 33.99\%, including a crisis surtax of 3\%. Also reduced tax rates can be applied when the taxable profit does not exceed $€ 322,500^{8}$.

\subsection{The Common Corporate Tax Base}

According to the EC proposal, no specific tax deductions are provided for in the CCTB. Concerning the simulations with ETA, we take into account the following tax rules:

- A distinction is made between long-life fixed assets with a useful life longer than or equal to 15 years and short to medium life fixed assets, with a useful life less than 15 years. Long-life fixed assets are depreciated individually on a straight-line base over their useful lives. For buildings, the depreciation rate equals $2.5 \%$. Other long-life tangible assets are depreciated at a rate of $6.67 \%$. Intangible assets are depreciated over the period for which the assets enjoy legal protection or for which the right is granted. If this period cannot be determined, the depreciation rate equals $6.67 \%$. Short to medium life fixed assets are depreciated together in one asset pool at an annual rate of $25 \%$ of the depreciation base.

- The depreciation base comprises any direct costs connected with the construction of a fixed asset. All research and development costs are deductible expenses.

- Concerning the valuation of inventories, we apply the WAC in the ETA, being the most favourable one.

- In order to avoid double taxation, domestic and foreign dividend income are exempt for $95 \%$.

- Income from interests and royalties are taxable, with a tax credit for withholding taxes paid.

- Interest expenses are generally deductible from the tax base. However, there is no deduction allowed for interests paid to associated companies resident for tax purposes in a low-tax country outside the EU, which does not exchange information. Because of technical matters, the ETA takes into account a 1:1 debt/equity ratio as TCR.

\section{Results}

\subsection{Belgian tax system}

The base case figure in Table 1 represents the Belgian tax burden for a large company

8 However, some corporations are excluded from the reduced tax rates. Concerning these conditions, we refer to the Belgian Corporate Income Tax Code of 1992. The SME firm in ETA meets all criteria to apply the reduced tax rates (e.g. taxable income $=131000$ ). 
resulting from simulations using the previous version of the $\mathrm{ETA}^{9}$. In what follows, we give depth to the Belgian corporate tax system by implementing the NID and the investment deduction or tax credit for patents. Applying these tax measures, we can a priori expect a decrease of the Belgian tax burden. The results in Table 1 reveal the size of this decline. The implementation of the tax measures mentioned above reduces the Belgian tax burden by $12.57 \%$. When looking at the isolated effects of the different measures, the results indicate that the decrease is mainly caused by the NID. This tax incentive leads to a reduction of $12.07 \%$. With respect to patents, Belgian companies have to choose between investment deduction or tax credit. As our large model firm is profitable, the impact of both alternatives is the same $(-0.50 \%)$.

Table 1. Effective tax burden and impact of particular tax categories Belgian tax system, large company (fiscal year 2011)

\begin{tabular}{llcc}
\hline & & Tax burden & Impact \\
\hline Base case Belgian Tax System & $35,152,405$ & \\
\hline Belgian Tax System: all options & & $30,732,669$ & $-12.57 \%$ \\
\hline & & & \\
\hline Impact Option & Notional Interest Deduction & $30,909,699$ & $-12.07 \%$ \\
\hline & Investment Deduction Patent & $34,975,375$ & $-0.50 \%$ \\
\hline & Tax Credit Patent & $34,975,376$ & $-0.50 \%$ \\
\hline
\end{tabular}

Table 2. Effective tax burden and impact of particular tax categories Belgian tax system, SME (fiscal year 2011)

\begin{tabular}{|c|c|c|c|}
\hline & & Tax burden & Impact \\
\hline Base case Belgian Tax System & & $1,230,717$ & \\
\hline Belgian Tax System: all options & & $1,094,071$ & $-11.10 \%$ \\
\hline \multirow[t]{3}{*}{ Impact Option } & Notional Interest Deduction & $1,098,811$ & $-10.72 \%$ \\
\hline & Investment Deduction Patent & $1,226,081$ & $-0.38 \%$ \\
\hline & Tax Credit Patent & $1,225,977$ & $-0.39 \%$ \\
\hline
\end{tabular}

We carry out the same simulations for a SME, taking into account the reduced corporate tax rates and the higher notional interest percentage. The results of these simulations are presented in Table 2. Comparing these results with those of a large company, the decrease is again mainly driven by the NID. However, despite the higher notional interest percentage for SMEs $(+0.5 \%)$, the caused decline in tax burden is smaller compared

9 The previous version of the ETA calculates the Belgian tax burden without taking into account the NID and the investment deduction or tax credit for patents. We consider the Belgian tax burden under the previous version as our 'base case' result. 
with large companies $(-10.72 \%$ instead of $-12.07 \%)$. This result is due to the fact that the average SME model disposes of a lower equity ratio than the average large company, which implies that the NID can be less exploited. Therefore, it could be suggested that SMEs may claim a higher notional interest to obtain decreases in tax burden that are similar to large companies. The results further indicate that the patent deduction for SMEs decreases the tax burden by $0.38 \%$ instead of $0.50 \%$ for large companies. This can be explained by the lower investment activities of the SME model. Moreover, we can remark that when SMEs choose for the tax credit this turns out to be more favourable $(-0.39 \%)$ than choosing for investment deduction $(-0.38 \%)$. This is caused by the fact that in case of an investment deduction, the reduced tax rates are applied whereas in case of a tax credit, the higher standard tax rate is used.

\subsection{Common Corporate Tax Base}

The changes of the effective tax burden induced by the adoption of the proposed CCTB regulations are displayed in Table 3 and Table 4, for a large company and SME respectively. It is assumed that the rules described in section 4 are implemented simultaneously. Since there is no intention to extend harmonization to corporate income tax rates, CCTB applies the Belgian tax rates.

Table 3. Changes in effective tax burden by adoption of CCTB and isolated impact of specific regulations, large company (fiscal year 2011)

\begin{tabular}{|c|c|c|c|}
\hline & & Tax burden & Impact \\
\hline Belgian Tax System: all options & & $30,732,669$ & \\
\hline CCTB: all options & & $35,556,551$ & $15.70 \%$ \\
\hline Base case Belgian Tax System & & $35,152,405$ & \\
\hline CCTB: all options & & $35,556,551$ & $1.15 \%$ \\
\hline \multirow[t]{5}{*}{ Impact CCTB Option } & Depreciation & $35,476,081$ & $0.92 \%$ \\
\hline & Buildings & $35,202,137$ & $0.14 \%$ \\
\hline & Machinery & $35,285,196$ & $0.38 \%$ \\
\hline & Equipment & $35,283,964$ & $0.37 \%$ \\
\hline & Valuation inventory & $35,241,597$ & $0.25 \%$ \\
\hline
\end{tabular}

The results in Table 3 reveal an increased tax burden when CCTB would be valid. Particularly, CCTB increases the Belgian tax burden by $15.70 \%$. This difference can be explained by the fact that under CCTB specific national tax incentives (deductions or tax credits) are not allowed. However, when we start from the base case, leaving the Belgian incentives out of consideration, CCTB would only increase the tax burden to a small extent $(1.15 \%)$. When looking at the isolated effects, the results indicate that 
Table 4. Changes in effective tax burden by adoption of CCTB and isolated impact of specific regulations, SME (fiscal year 2011)

\begin{tabular}{|c|c|c|c|}
\hline & & Tax burden & Impact \\
\hline Belgian Tax System: all options & & $1,094,071$ & \\
\hline CCTB: all options & & $1,249,231$ & $14.18 \%$ \\
\hline Base case Belgian Tax System & & $1,230,717$ & \\
\hline CCTB: all options & & $1,249,231$ & $1.50 \%$ \\
\hline \multirow[t]{2}{*}{ Impact CCTB Option } & Depreciation & $1,244,601$ & $1.13 \%$ \\
\hline & Valuation inventory & $1,235,177$ & $0.36 \%$ \\
\hline
\end{tabular}

the increase is mainly caused by the differences in depreciation rules. With respect to buildings, the Belgian as well as the CCTB system apply the straight line method. CCTB sets the useful life for buildings to 40 years, regardless of the type of building. Contrary, Belgium prescribes a useful life for office buildings of 33 years and allows a shorter depreciation period of 20 years for industrial buildings. Thus, the adoption of the common depreciation rules for buildings, which are more restrictive, causes an increase in the effective tax burden of $0.14 \%$. Concerning machinery and equipment, the double declining method is used for Belgium. The results indicate that this leads to a smaller tax burden than the one reflected by the standard depreciation rate of $25 \%$ for asset pools under the proposed CCTB $(0.38 \%$ for machinery and $0.37 \%$ for equipment $)$. The last row of Table 3 shows the impact of the valuation of inventory. For CCTB the weighted-average-cost (WAC) method is chosen as an option, while for Belgium the LIFO method is applied. Assuming rising prices, the LIFO method leads to higher expenditures and results in a lower tax burden compared with the WAC method $(0.25 \%)$. Table 4 presents the tax burden for a SME under both the Belgian and CCTB system. Comparing these results with those of a large company, CCTB increases the Belgian tax burden to a comparable, but somewhat lesser degree (14.18\%).

\subsection{Sensitivity analysis: economic model assumptions}

As a robustness check we determine how changes in economic model assumptions influence the effect of a simultaneous introduction of all CCTB options. ${ }^{10}$ More specific, the effects of the changes in the firm's capital intensity, profitability and capital structure are simulated and reported in Table 5.

To measure the impact of the model firm's capital intensity on the tax burden in case of a CCTB, the share of tangible assets to total assets is raised (or lowered) by $5 \%$,

${ }^{10}$ As benchmark case we consider the tax burden under the Belgian tax system taking into account the NID. We do not take into consideration the investment deduction or tax credit for patents as their impact is small. 


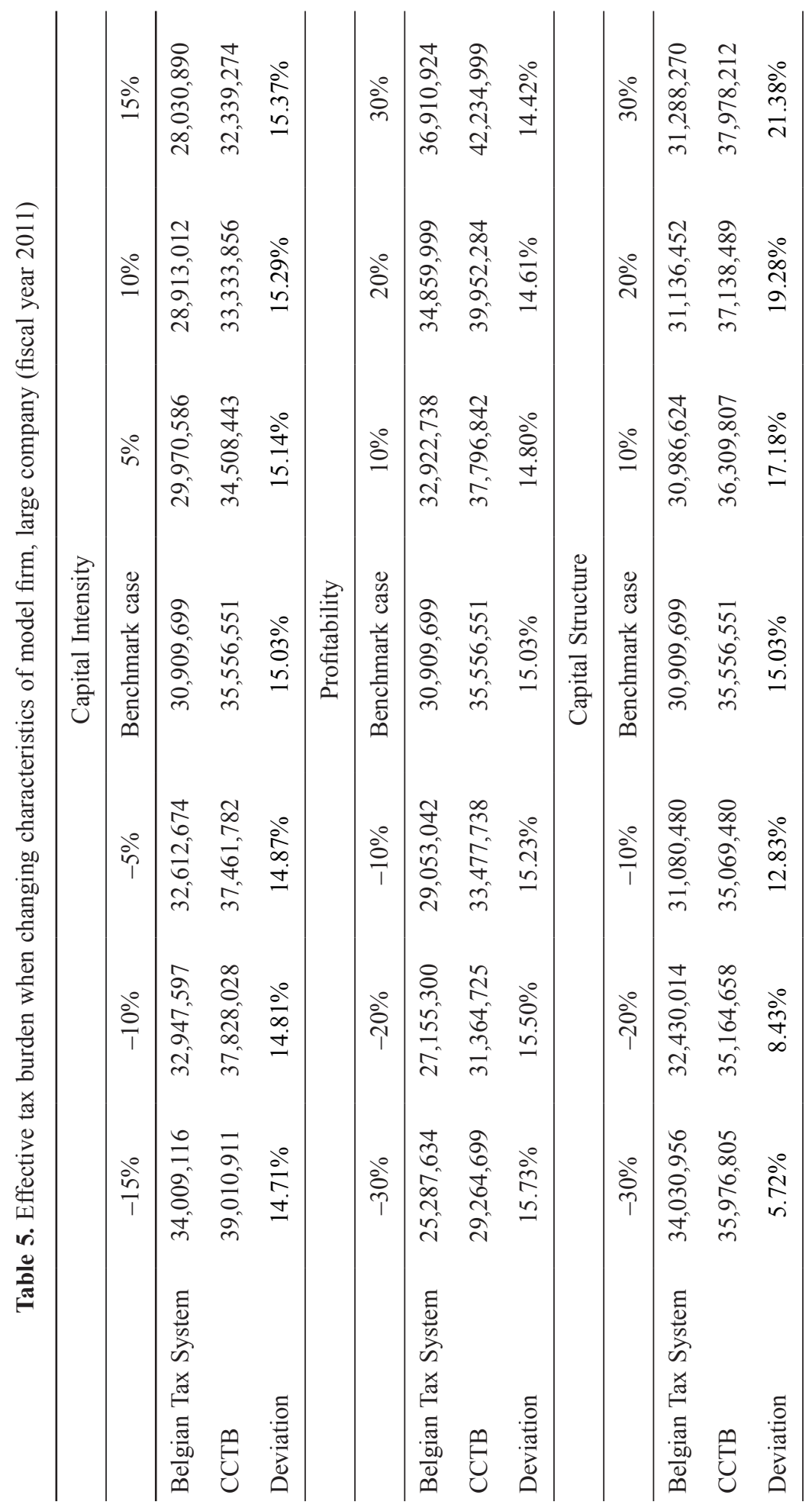


$10 \%$ and $15 \%$ with respect to the benchmark case. In return, long term receivables are reduced (or increased) accordingly to leave the sum of all assets unchanged. In general, the results show that the tax burden under both systems decreases as the capital intensity becomes higher, i.e. more depreciation costs are deducted from the tax base. Comparing CCTB with the Belgian tax system, the tax burden according to the Belgian tax rules decreases faster due to its more favourable depreciation methods.

Apart from capital intensity, profitability is another factor that influences the tax burden. To measure this impact, the return on sales ratio is modified by changing sales revenues and keeping expenses stable. Increases and decreases of $10 \%, 20 \%$ and $30 \%$ are considered. The results in Table 5 show that the tax burden under both systems increases as sales revenues rise. As expenses like the NID are kept fixed, the tax burden under the Belgian tax system increases faster as this measure becomes less influential with growing profit.

The final analysis deals with the capital structure, i.e. the equity/debt ratio. This ratio is lowered or increased by $10 \%, 20 \%$ and $30 \%$. When the equity ratio is higher than the benchmark case, the tax burden increases under both systems as less interests are deductible. In front of that, an equity ratio that is lower than the base case should decrease the tax burden as more interests accrue. The results, however, show that from a certain amount of debt, the tax burden increases under both systems. This can be explained by the working of the thin capitalization rule that restricts the deduction of interest to a debt/equity ratio of $1: 1$. For the Belgian system, lowering the equity ratio even causes a bigger increase because of a twofold effect: on the one hand, the thin cap rule applies, on the other hand, the benefit of the NID becomes smaller.

\section{Conclusions}

As the published proposal for a CCCTB lacks clarity about the technical details of consolidation and apportionment, a CCTB would be the most achievable option in the short term. In a recent study, Spengel et al. (2012) use the ETA to simulate the impact of a CCTB on the effective tax burden of companies in the 27 EU member states. However, given the large scale of their study, it is unfeasible to address all national tax regulations in great detail. To fill this gap in the literature, we focus on the impact of CCTB on the effective tax burden for Belgian companies in particular.

The results show that the introduction of CCTB would broaden the Belgian tax base and lead to an increase of the tax burden by $15.70 \%$. This increase can be mainly explained by the fact that under CCTB specific national tax incentives like the NID are not allowed. Furthermore, CCTB applies less favourable depreciation and inventory valuation methods. As a robustness check, we look how changes in economic model assumptions influence the tax burden. Under both tax systems, increasing profitability and equity leads to a higher tax burden, whereas an increasing capital intensity leads to a lower tax burden. When comparing the CCTB with the Belgian tax system, the biggest differences in increase or decrease occur when the company is characterized by low profitability, high capital intensity and high equity. 
If CCTB would be introduced as an optional tax system, Belgian companies will only choose for the new tax system if, at least, it does not increase their current tax burden in the short-term. In this respect, we could make some policy recommendations. Given the base broadening under CCTB, Belgian policymakers could reduce the corporate income tax rate without changing the tax income. As the statutory tax rate is an important determinant of location decisions (Devereux et al. 2002), this could increase the attractiveness of Belgium for multinational investors. Another option Belgian policymakers could consider, is to convince Europe that the NID should be allowed under CCTB. This seems a feasible option, given the fact that other EU countries like Italy and Latvia already have experiences with a form of ACE (Parillo 2012). For example, Italy allows domestic companies and Italian braches of foreign companies to apply a tax deduction computed as 3\% of the equity formed after 2010 (Panteghini et al. 2012). Notwithstanding our contribution to the current literature, we have to deal with some shortcomings of our study. While our analysis focuses on the effective tax burden effects of a CCTB, our simulations do not capture all possible elements determining the desirability of such harmonization. Our analysis, for example, ignores the possible savings of compliance and administrative costs for multinationals. As studies in this field are scarce, this would be an interesting topic for future research. Moreover, our study simulates the effects of a CCTB on the effective tax burden in Belgium, leaving the consolidation and apportionment out of consideration. However, consolidation would increase the advantages for companies as it would introduce automatic cross border loss compensation. Therefore, further research in this area would be interesting.

\section{Acknowledgements}

We thank Christoph Spengel from the University of Mannheim and Maria-Theresia Evers, Benedikt Zinn and Katharine Finke from the Zentrum für Europaïsche Wirtschaftsforschung (ZEW) for assisting with the calculations in the ETA. Financial support from the 'Research Fund University College Ghent' is gratefully acknowledged.

\section{References}

Belgian Bulletin of Acts. 1999. Corporation Code.

Belgian Bulletin of Acts. 1992. Income Tax Code.

Bettendorf, L.; Devereux, M. P.; van der Horst, A.; Loretz, S.; de Mooij, R. A. 2010. Corporate tax harmonization in the EU, Economic Policy 25(63): 537-590. http://dx.doi.org/10.1111/j.14680327.2010.00248.x

Devereux, M. P.; Griffith, R.; Klemm, A. 2002. Corporate income tax reforms and international tax competition, Economic Policy 17(35): 449-495. http://dx.doi.org/10.1111/1468-0327.00094

Devereux, M.P.; Griffith, R. 2003. Evaluating Tax Policy for Location Decisions, International Tax and Public Finance 10(2): 107-126. http://dx.doi.org/10.1023/A:1023364421914

European Commission. 2001. Towards an internal market without tax obstacles, Working paper COM(2001) 582 final. Brussels.

European Commission. 2011. Proposal for a council directive on a common consolidated corporate tax base, Working paper COM2011 121/4. Brussels. 
Finke, K.; Heckemeyer J.; Reister, T.; Spengel, C. 2013. the impact of tax rate cut cum base broadening reforms on heterogeneous firms - learning from the German tax reform of 2008, Finanzarchiv 69(1): 72-114. http://dx.doi.org/10.1628/001522113X663488

Fullerton, D. 1984. Which effective tax rate?, National Tax Journal 37(1): 23-41.

Haverals, J. 2007. IAS \IFRS in Belgium: quantitative analysis of the impact on the tax burden of companies, Journal of International Accounting, Auditing \& Taxation 16(1): 69-89.

http://dx.doi.org/10.1016/j.intaccaudtax.2007.01.005

Kestens, K.; Van Cauwenberge, P.; Christiaens, J. 2012. The effect of the notional interest deduction on the capital structure of Belgian SMEs, Environment and Planning C-Government and Policy 30(2): 228-247. http://dx.doi.org/10.1068/c1163b

Klemm, K. 2007. Allowance for corporate equity, CESinfo Economic Studies 53(2): 229-262. http://dx.doi.org/10.93/cesifo/ifm007

Oestreicher, A.; Koch, R. 2011. The revenue consequences of using a Common Consolidated Corporate Tax Base to determine taxable income in the EU member states, Finanzarchiv 67(1): 64-102. http://dx.doi.org/10.1628/001522111X574191

Oestreicher, A.; Reister, T.; Spengel, C. 2009. Common Corporate Tax Base (CCTB) and effective tax burdens in the EU member states, World Tax Journal 1: 46-66.

Panteghini, P.; Parisi, M. L.; Pighetti, F. 2012. Italy's ACE tax and its effect on a firm's leverage, Economic Discussion papers, no. 2012-31, Kiel Institute for the World Economy.

Parillo, K. 2012. The allowance for corporate equity and the CCCTB: more efficient ways to tax corporate income?, Worldwide Tax Daily 117-2.

Schanz, D.; Schanz, S. 2010. Finding a new corporate tax base after the abolishment of the onebook system in EU member states, European Economic Review 19(2): 311-341.

http://dx.doi.org/10.1080/09638180903384627

Schön, W.; Screiber, U.; Spengel, C. 2008. A Common Consolidated Corporate Tax Base for Europe. Berlin Heidelberg: Springer. http://dx.doi.org/10.1007/978-3-540-79484-4

Spengel, C.; Ortmann-Babel, M.; Zinn, B.; Matenaer, S. 2012. A Common Corporate Tax Base for Europe: an impact assessment of the draft council directive on a CC(C)TB, World Tax Journal 4: $185-221$.

Spengel, C.; Oestreicher, A. 2012. Common Corporate Tax Base in the EU: impact on the size of tax bases and effective tax burdens, ZEW Economic Studies 43: 1-175.

Valenduc, C. 2004. Corporate income tax and the taxation of income from capital: some evidence from the past reforms and the present debate on corporate income taxation in Belgium, Working Paper No. 6. DG Taxation and Customs Union.

Vandenbussche, H.; Crabbé, K.; Janssen, B. 2005. Is there regional tax competition: firm level evidence for Belgium, De Economist 153(3): 257-276.

http://dx.doi.org/10.1007/s10645-005-1988-6

Annelies ROGGEMAN and Isabelle VERLEYEN are PhD students at the University College Ghent/ Ghent University, where they carry out research concerning the evaluation of the Common Consolidated Corporate Tax Base.

Philippe VAN CAUWENBERGE is a Professor at the Department of Accountancy and Corporate Finance of the Ghent University. His research has been published in journals like Public Choice, Abacus and Public Money and Management.

Carine COPPENS is the Head of the Department of Financial Management at the University College Ghent, Faculty of Business and Information Management. 